\title{
NATURAL HISTORY OF DUCTAL CARCINOMA IN SITU História natural do carcinoma ductal in situ
}

Nayara Alves de Freitas Lemos ${ }^{1}$, Ruffo Freitas-Junior²*, Marise Amaral Rebouças Moreira ${ }^{3}$, Fábio Francisco Oliveira Rodrigues ${ }^{4}$

\section{ABSTRACT}

Ductal carcinoma in situ (DCIS) has been detected more frequently in the last decades using the mammographic screening. The objective of the present study was to review the epidemiological aspects of DCIS. A bibliographic narrative review was carried out focusing on the following aspects: the epidemiology of DCIS to discuss subtypes; natural history; screening; and survival. It was possible to verify that the DCIS is currently considered a precursor lesion of breast cancer, presenting a considerable and uneven increased incidence between developed and developing countries, probably due to the inclusion of mammographic screening programs. There are controversies regarding the benefit or not of its detection, diagnosis, treatment and survival of patients with DCIS. It is concluded that the considerable increase in the incidence of DCIS raises an important discussion about the real need for its diagnosis as well as its real biological significance.

KEYWORDS: noninfiltrating intraductal carcinoma; breast neoplasms; epidemiology; incidence; carcinoma in situ.

\section{RESUMO}

O carcinoma ductal in situ (CDIS) tem sido detectado com maior frequência nas últimas décadas a partir do rastreamento mamográfico. O objetivo do presente estudo foi revisar os aspectos epidemiológicos do CDIS. Foi realizada uma revisão bibliográfica narrativa enfocando os aspectos do CDIS: epidemiologia, para discussão a respeito dos subtipos; história natural; rastreamento; e sobrevida. Foi possível verificar que o CDIS é atualmente considerado como uma lesão precursora do câncer de mama e apresenta aumento considerável e desigual em sua incidência entre países desenvolvidos e em desenvolvimento, devido, provavelmente, à inclusão dos programas de rastreamento mamográfico. Há controversas quanto ao benefício ou não da detecção, do diagnóstico, do tratamento e da sobrevida de pacientes que apresentam o CDIS. Conclui-se que o aumento considerável da incidência do CDIS levanta importante discussão sobre a necessidade real de seu diagnóstico, bem como do seu real significado biológico.

PALAVRAS-CHAVE: carcinoma intraductal não infiltrante; neoplasias da mama; epidemiologia; incidência; carcinoma in situ.

Study carried out at Rede Goiana de Pesquisa em Mastologia - Goiânia (GO), Brazil.

${ }^{1}$ Rede Goiana de Pesquisa em Mastologia - Goiânia (GO), Brazil.

²Universidade Federal de Goiás - Goiânia (GO), Brazil.

${ }^{3}$ School of Medicine, Universidade Federal de Goiás - Goiânia (GO), Brazil.

${ }^{4}$ Instituto do Câncer Dr. Arnaldo Vieira de Carvalho - São Paulo (SP), Brazil.

*Corresponding author: ruffojr@terra.com.br

Conflict of interest: nothing to declare.

Finance source: Study financed by the Coordination of Improvement of Higher Education Personnel (CAPES).

Received on: 10/04/2017. Accepted on: 11/05/2017 


\section{DUCTAL CARCINOMA IN SITU}

Ductal carcinoma in situ (DCIS) comprises heterogeneous lesions resulting from abnormal cell proliferation in the mammary ducts, characterized by non-invasion of the basement membrane; its differentiation from atypical ductal hyperplasia (ADH) is complex, taking into account the number of layers of proliferated cells and the wide variety of interobserver interpretation due to the proliferation of the number of cell layers ${ }^{1}$. Although a different terminology was proposed for DCIS, the World Health Organization (WHO), in their last consensus, in 2012, chose to maintain the classical nomenclature of intraductal proliferative lesions ${ }^{2}$. According to the TNM classification of the Union for International Cancer Control (UICC), DCIS is defined as Tis (DCIS) ductal carcinoma in situ, stage 0 (TisN0M0) ${ }^{3}$. Based on its architectural characteristics, the DCIS is classified into four morphologies: micropapillary, cribriform, solid and comedo 1 .

\section{EPIDEMIOLOGY}

DCIS has been detected more frequently in the last decades, which calls the attention of medical surgeons, pathologists and researchers. Of rare occurrence in the mid-1970s, since the introduction of mammographic screening programs, it has accounted for approximately $20 \%$ of breast cancer cases detected in countries where there is organized population screening. This increase has been most observed among women over 50 years of age (Table 1$)^{5}$.

The prevalence is higher in White women, followed by Hispanic Whites, Black and Asians in the Pacific region ${ }^{6}$. The incidence of DCIS, when adjusted for age, is higher among Caucasian women, followed by African American and Asian women in the Pacific region, compared to Latin American women?. In Brazil, little information has been published on the epidemiology of carcinomas in situ ${ }^{8}$. It is estimated that its incidence varies between 6.6 and $8.9 \%^{9-11}$. In Goiânia, data from the Population-Based Cancer Registry showed a significant increase in carcinoma in situ cases, from 0.2 to $6.2 \%$ between 1989 and $2003^{10}$.

\section{MAMMOGRAPHY SCREENING}

Because DCIS is not specifically screened, it is diagnosed more frequently as a consequence of screening for invasive breast cancer. As its etiology is presumably heterogeneous, prognostic evaluation based on pathology and imaging findings is highly variable ${ }^{12}$.

Table 1. New estimated cases of female breast cancer and deaths by age in the United States, 2013.

\begin{tabular}{l|c|c|c} 
Age & In situ cases & Invasive cases & Deaths \\
\hline$<40$ & 1,900 & 10,980 & 1,020 \\
\hline$<50$ & 15,650 & 48,910 & 4,780 \\
\hline $50-64$ & 26,770 & 84,210 & 11,970 \\
\hline $65+$ & 22,220 & 99,220 & 22,870 \\
\hline All ages & 64,640 & 232,340 & 39,620 \\
\hline
\end{tabular}

If, on the one hand, the mammography screening allows a considerable increase in the diagnosis of initial tumors and a substantial increase in the number of DCIS cases, on the other, this strategy of secondary prevention has also led to an increase in the so-called superdiagnosis ${ }^{13}$. This term is used for DCISs that would not evolve into the invasive variant and are nevertheless detected by screening exams ${ }^{14}$. Cases of superdiagnosis are reported more frequently on low-grade nuclear DCIS ${ }^{15,16}$ in which active surveillance and individualization of treatments should be based on prospective studies ${ }^{13}$.

Although there is controversy, the benefit of the mammography screening in terms of saved lives is greater than the excess of diagnoses, since for each case of superdiagnosis, three lives are saved in groups of women submitted to the screening ${ }^{17}$.

In Brazil, the connection between the adequate mammography screening and the incidence of DCIS can be indirectly verified, with data from the population screening program in the Barretos region: there is a $20 \%$ incidence of DCIS among all tumors detected between 2003 and $2010^{18}$. Table 2 summarizes the prevalence of DCIS reported in Brazil between 2000 and 2014.

\section{RISK FACTORS}

Regarding risk reduction factors related to breast cancer, Inumaru et al. ${ }^{19}$ highlighted lactation and the practice of physical activities, both pre- and post-menopausal. The change in women's lifestyle has been indicated as an important factor related to the increase in the incidence of breast cancer ${ }^{20}$. Currently, women schedule less pregnancies, breastfeed for a shorter period, or even choose not to have children; when they do so, it usually is later on. In addition, they adopt unhealthy lifestyle habits, which lead to an increased body mass index, also considered a risk factor ${ }^{12}$. In less developed countries, the incidence of breast cancer is higher in premenopausal women, because the female population is younger and postmenopausal risk factors are not present ${ }^{21}$. Decreased use of postmenopausal hormone therapy has been suggested as responsible for the decline in the incidence of invasive breast cancer since $2003^{22}$.

For DCIS, the association with the use of hormones (estrogen and progesterone), or even an increase in the estimation of time-dependent risk, would be uncertain ${ }^{23}$. However, a study conducted in Norway involving 681 cases of DCIS, registered a $1.61 \%$ risk related to the long-term use of combinations of estrogen and progesterone ${ }^{24}$.

Table 2. Prevalence of cases of ductal carcinoma in situ in Brazil until 2014

\begin{tabular}{l|c|c|c} 
City - State & Period/year & $\begin{array}{c}\text { Total of } \\
\text { DCIS cases }\end{array}$ & $\begin{array}{c}\text { DCIS } \\
\text { prevalence (\%) }\end{array}$ \\
\hline São Carlos-SP & 2000 to 2004 & 106 & 6.6 \\
\hline São Paulo-SP & 2012 to 2014 & 288 & 8.1 \\
\hline Lavras - MG & 2008 to 2013 & 112 & 8.9 \\
\hline
\end{tabular}

DCIS: ductal carcinoma in situ. 


\section{NATURAL HISTORY}

Evidence on the natural history of the progression of invading DCIS refers to different malignant changes in the ductal epithelium ${ }^{25}$, which is associated with different stages in the progression to a subsequent invasive carcinoma. However, the proportion of untreated DCIS that will develop to invasive breast cancer is unknown ${ }^{12}$.

It is observed that the cells most prone to invasion are located at the end of the duct which is regulated, preferably, by the mechanisms of adhesion and cellular contractility. During the progression of breast cancer, there are cellular morphological alterations in which the cribriform and comedo subtypes represent the final stages of DCIS ${ }^{26}$. Figures 1 to 3 illustrate the DCIS in different nuclear grades and histological subtypes.

Neoplastic cells in DCISs and in invasive ductal carcinomas show similarities at molecular levels that translate into similar

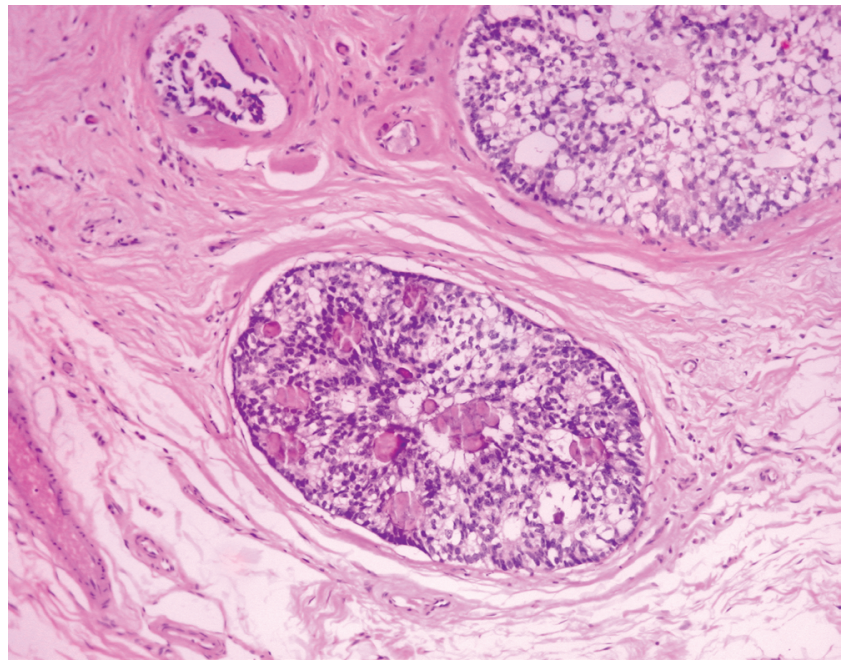

Figure 1. Ductal carcinoma in situ stage I, cribriform with foci of calcification (HE 100x).

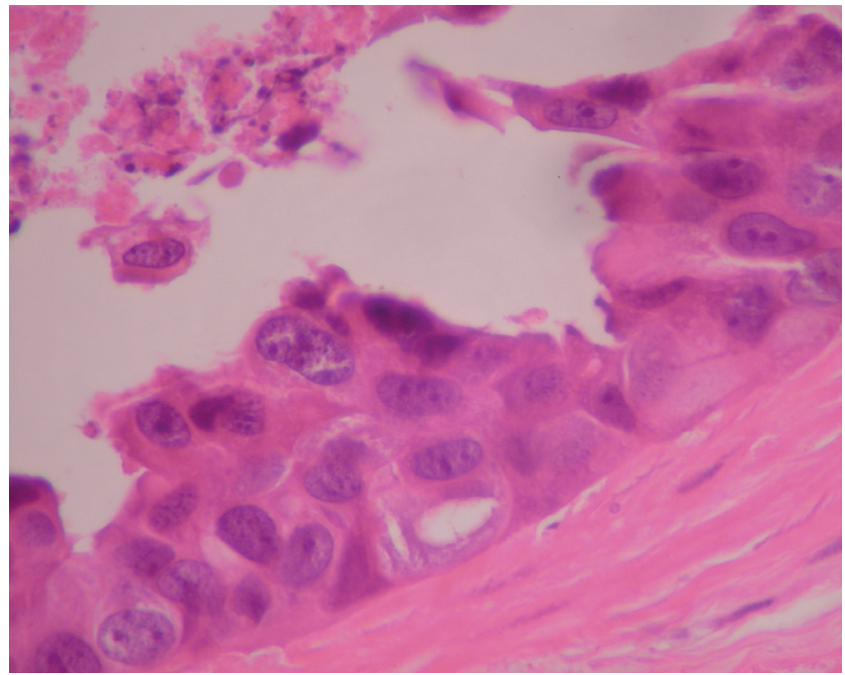

Figure 2. Ductal carcinoma in situ stage III, comedocarcinoma (HE 400x). global profiles of gene and immunophenotypic expression ${ }^{27}$. The biological differences between DCIS and invasive breast carcinoma have not yet been adequately identified ${ }^{28}$, and the main known molecular phenotypes found in invasive breast cancer are similar, but different in prevalence ${ }^{29}$. Estrogen receptor expression is strongly associated with low grade DCIS, whereas HER2 overexpression is linked to high grade DCIS ${ }^{27}$.

Current evidences suggest that the transition from carcinoma in situ to invasive breast cancer depends on microenvironmental interactions, since the levels of change in DCIS genomic copy numbers correlate positively with the presence of immune cells, and that the invasive disease could require a number of copies leading to tumor "immunosuppression"30. The expression of tumor-infiltrating lymphocytes is higher in high-grade nuclear DCIS, with comedo necrosis, negative RE and positive HER $2^{30}$.

In many cases, myoepithelial cells are abnormal presenting loss of function of tumor suppressor genes ${ }^{31}$. In addition, the interaction between stromal and epithelial cells contributes to the phenomenon of tumor cells invasion ${ }^{31}$.

\section{SURVIVAL}

Women with a diagnosis of DCIS have high global survival rates and are close to $100 \%^{32-35}$, as shown in Table 3 . These studies relate

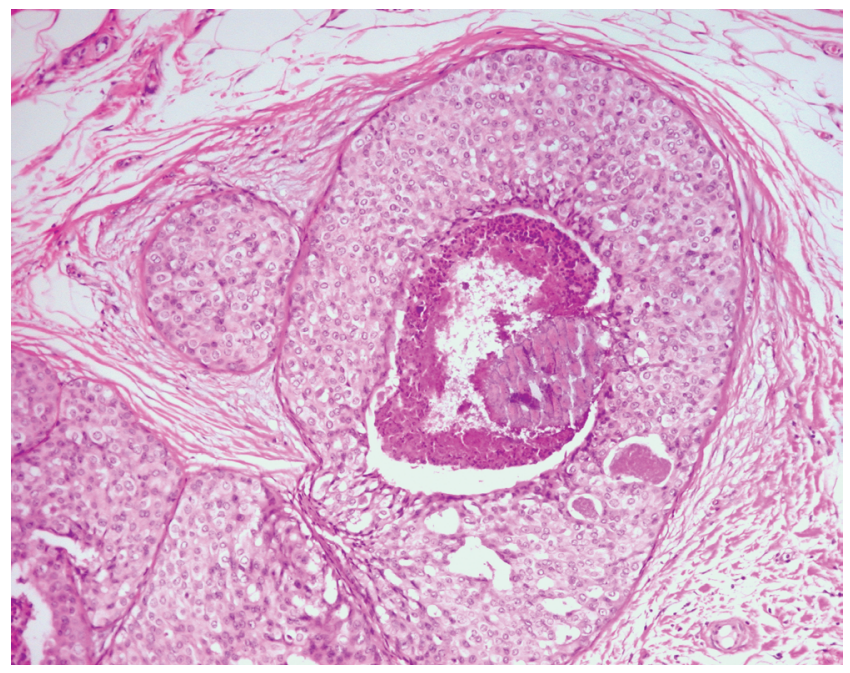

Figure 3. Ductal carcinoma in situ stage II (HE 200x).

Table 3. Surviv al rates reported for women with ductal carcinoma in situ.

\begin{tabular}{l|c|c|c|c} 
& $\begin{array}{c}\text { Sagara } \\
\text { et al., } \\
\mathbf{2 0 1 5}(\%)\end{array}$ & $\begin{array}{c}\text { Shikama } \\
\text { et al., } \\
\mathbf{2 0 1 5}(\%)\end{array}$ & $\begin{array}{c}\text { Worni } \\
\text { et al., } \\
\mathbf{2 0 1 5}(\%)\end{array}$ & $\begin{array}{c}\text { Wadsten } \\
\text { et al., } \\
\mathbf{2 0 1 6}(\%)\end{array}$ \\
\hline $\begin{array}{l}\text { Cancer-specific } \\
\text { survival }\end{array}$ & 98.4 & 91 & - & 97 \\
\hline Global survival & 89.3 & 97 & 98 & - \\
\hline
\end{tabular}


the following factors of higher local survival: low nuclear grade DCIS; conservative surgery associated with radiotherapy; and free surgical margins ${ }^{36,37}$.

The benefit of surgery for low nuclear grade DCIS is lower than in intermediate and high grade cases, compared to the results of a large study using data from Surveillance, Epidemiology, and End Results Program(SEER). Patients with low nuclear grade tumors who did not receive surgical treatment presented as little chance of evolution as those who received it, unlike women with high nuclear grade DCIS ${ }^{32}$.

In prospective studies, there are increased rates of disease-free survival in patients with DCIS who have used Tamoxifen, especially when associated with conservative surgery and radiotherapy, as well as in young patients with positive estrogen receptors ${ }^{36,37}$.

The number of invasive relapses is lower when DCIS cases are detected by screening methods compared to symptomatic DCIS, in addition to patients having longer disease-free surviva $\left.\right|^{37}$. Low recurrence rates are found in patients treated with mastectomy ${ }^{38}$.
The rates of DCIS relapse are of the order of 10 to $35 \%$, considering risk factors: high nuclear grade; compromised margins; and women younger in age ${ }^{16,38,39}$, in this scenario about $35 \%$ occur in an invasive manner ${ }^{40}$.

From the review, there is controversy regarding the detection of DCIS. On the one hand, greater survival, on the other, superdiagnosis. Thus, it is necessary for the DCIS to be considered with special attention in order to know its natural history, which would change the understanding for its approach and reduce the need for screening.

\section{ACKNOWLEDGEMENT}

To the research team of the Programa de Mastologia do Centro Avançado de Diagnóstico da Mama (CORA) at Goiânia and of the Population-Based Cancer Registry of Goiania. To the Cordination of Improvement of Higher Education Personnel (CAPES).

\section{REFERENCES}

1. Ni YB, Tse GM. Pathological criteria and practical issues in papillary lesions of the breast - a review. Histopathology. 2016;68(1):22-32. DOI: 10.1111/His.12866

2. Gobbi H. Classificação dos tumores da mama: atualização baseada na nova classificação da organização mundial da saúde de 2012. J Bras Patol Med Lab. 2012;48(6):463-74.

3. Sobin LH, Compton CC. TNM seventh edition: what's new, what's changed communication from the international union against cancer and the American joint committee on cancer. Cancer. 2010;116(22):5336-9. DOI: 10.1002/cncr.25537

4. American Cancer Society. Breast Cancer Facts \& Figures 20092010. Atlanta: American Cancer Society, Inc.

5. DeSantis C, Ma J, Bryan L, Jemal A. Breast cancer statistics, 2013. CA Cancer J Clin. 2014;64(1):52-62. DOI: 10.3322/ caac. 21203

6. Horner MJ, Ries LA, Krapcho M, Neyman N, Aminou R, Howlader N, et al. SEER cancer statistics review, 1975-2006, National Cancer Institute. J Pancreas 2010;11(2):153-6.

7. Innos K, Horn-Ross PL. Recent trends and racial/ethnic differences in the incidence and treatment of ductal carcinoma in situ of the breast in California women. Cancer. 2003;97(4):1099-106. DOI: 10.1002/Cncr.11104

8. Martins E, Freitas-Junior R, Curado MP, Freitas NM, Oliveira JC, Silva CM. Evolução temporal dos estádios do câncer de mama ao diagnóstico em um registro de base populacional no Brasil central. Rev Bras Ginecol Obstet. 2009;31(5):219-23. DOI: 10.1590/S0100-72032009000500003

9. Macchetti AH. Estadiamento do câncer de mama diagnosticado no sistema público de saúde de São Carlos. Medicina Ribeirão Preto. 2007;40(3):394-402.

10. Gebrim LH, Shida JY, Hegg R, Mattar TT. Avaliação do tempo de início do tratamento, estadiamento histopatológico e positividade dos biomarcadores (RE, RP, HER-2) em
3.566 pacientes tratadas pelo SUS no período de 2012 a 2014, no Hospital Pérola Byington. Rev Bras Mastologia. 2014;24(3):65-69. DOI: 10.5327/Z201400030002RBM

11. HaddadCF. Características clínico-patológicas e estadiamento ao diagnóstico de pacientes com câncer de mama em um centro de saúde do interior de Minas Gerais. Rev Bras Mastologia. 2014;24(4):103-108. DOI: 10.5327/Z20140003RBM.

12. Allegra CG, Aberle DR, Ganschow P, Hahn SM, Lee CN, MillonUnderwood S, et al. National institutes of health state-of-thescience conference statement: diagnosis and management of ductal carcinoma in situ. J Nat Cancer Instit. 2010;102(3):161-9. DOI: 10.1093/jnci/djp485

13. Falk RS, Hofvind S, Skaane P, Haldorsen T. Overdiagnosis among women attending a population-based mammography screening program. Int J Cancer. 2013;133(3): 705-12. DOI: 10.1002/ijc.28052

14. Lynge E, Ponti A, James T, Májek O, von Euler-Chelpin M, Anttila A, et al. Variation in detection of ductal carcinoma in situ during screening mammography: a survey within the international cancer screening network. Eur J Cancer. 2014;50(1):185-92. DOI: 10.1016/j.ejca.2013.08.013

15. Kanematsu M, Morimoto M. Takahashi M, Honda J, Bando Y, Moriya T, et al. Thirty percent of ductal carcinoma in situ of the breast in Japan is extremely low-grade ER(+)/HER2(-) type without comedo necrosis. J Med Invest. 2016;63(3-4):192-8. DOI: 10.2152/Jmi.63.192

16. Luijt PA, Heijnsdijk EA, Fracheboud J, Overbeek LI, Broeders MJ, Wesseling J. et al. The distribution of ductal carcinoma in situ (DCIS) grade in 4232 women and its impact on overdiagnosis in breast cancer screening. Breast Cancer Res. 2016;18(1):47. DOI: 10.1186/S13058-016-0705-5

17. Ghanouni A, Meisel SF, Renzi C, Wardle J, Waller J. Survey of public definitions of the term 'overdiagnosis' in the UK. BMJ Open. 2016;6:e010723. DOI: 10.1136/bmjopen-2015-010723 
18. Tsunoda AT, Nunes JS, Watanabe AP, Santos-Junior LA, Mauad EC, Brentani RR. Controle de qualidade em rastreamento mamográfico no Brasil: experiência do Hospital de Câncer de Barretos. Rev Bras Mastologia. 2013;23(1):12-18.

19. Inumaru LE, Silveira EA, Naves MM. Risk and protective factors for breast cancer: a systematic review. Cad Saude Publica. 2011;27(7):1259-70

20. Advani P, Moreno-Aspitia A. Current Strategies for the prevention of breast cancer. Breast Cancer: Targets and Therapy. 2014;6:59-71.

21. Ghiasvand R, Adami HO, Harirchi I, Akrami R, Zendehdel $\mathrm{K}$. Higher incidence of premenopausal breast cancer in less developed countries; myth or truth? BMC Cancer. 2014;14:343. DOI: $10.1186 / 1471-2407-14-343$

22. Kerlikowske K. Epidemiology of ductal carcinoma in situ. J Natl Cancer Inst Monogr. 2010;2010(41):139-41. DOI: 10.1093/ jncimonographs/lgq027

23. Calvocoressi L. Stowe MH, Carter D, Claus EB. Postmenopausal hormone therapy and ductal carcinoma in situ: a population-based case control study. Cancer Epidemiol. 2012;36(2):161-8. DOI: 10.1016/j.canep.2012.01.001

24. Suhrke P, Zahl PH. Breast cancer incidence and menopausal hormone therapy in Norway from 2004 to 2009: a register-based cohort study. Cancer Med. 2015;4(8):1303-8. DOI: 10.1002/ Cam4.474

25. Badruddoja M. Ductal carcinoma in situ of the breast: a surgical perspective. Int J Surgical Oncology. 2012;2012:12. DOI: $10.1155 / 2012 / 761364$

26. Boghaert E, Radisky DC, Nelson CM. Lattice-based model of ductal carcinoma in situ suggests rules for breast cancer progression to an invasive state. PLoS Comput Biol. 2014;10(12):e1003997. DOI: 10.1371/Journal.Pcbi.1003997

27. Rohilla M, Bal A, Singh G, Joshi K. Prediction of heterogeneity in breast cancer immunophenotype at ductal carcinoma in situ stage? J Cancer Res Ther. 2016;12(4):1249-56. DOI: 10.4103/0973-1482.199541

28. Allred DC. Ductal carcinoma in situ: terminology, classification, and natural history. J Natl Cancer Inst Monogr. 2010;2010(41):134-8. DOI: 10.1093/jncimonographs/lgq035

29. Tamimi RM., Baer HJ, Marotti J, Galan M, Galaburda L, $\mathrm{Fu}$ Y, et al. Comparison of molecular phenotypes of ductal carcinoma in situ and invasive breast cancer. Breast Cancer Res. 2008;10(4):R67. DOI:10.1186/Bcr2128

30. Hendry S, Pang JB, Byrne DJ, Lakhani SR, Cummings MC, Campbell IG, et al. Relationship of the breast ductal carcinoma in situ immune microenvironment with clinicopathological and genetic features. Clin Cancer Res. 2017;23(17):5210-7. DOI: 10.1158/1078-0432.CCR-17-0743
31. Kuerer HM, Albarracin CT, Yang WT, Cardiff RD, Brewster AM, Symmans WF, et al. Ductal carcinoma in situ: state of the science and roadmap to advance the field. J Clin Oncol. 2009;27(2):279-88. DOI: 10.1200/JCO.2008.18.3103

32. Sagara Y, Mallory MA, Wong S, Aydogan F, DeSantis S, Barry WT, et al. Survival benefit of breast surgery for low-grade ductal carcinoma in situ: a population-based cohort study. JAMA Surg. 2015;150(8):739-45. doi: 10.1001/jamasurg.2015.0876

33. Wadsten C, Heyman H, Holmqvist M, Ahlgren J, Lambe $\mathrm{M}$, Sund $\mathrm{M}$, et al. A validation of DCIS registration in a population-based breast cancer quality register and a study of treatment and prognosis for DCIS during 20 years. Acta Oncol. 2016;55(11):1338-43. DOI: 10.1080/0284186X.2016.1211317

34. Shikama N, Sekiguchi K, Nakamura N, Sekine H, Nakayama Y, Imanaka K, et al. Final results from a multicenter prospective study (JROSG 05-5) on postoperative radiotherapy for patients with ductal carcinoma in situ with an involved surgical margin or close margin widths of $1 \mathrm{~mm}$ or less. J Radiat Res. 2015;56(5):830-4. DOI: 10.1093/jrr/rrv034

35. Lo AC, Truong PT, Wai ES, Nichol A, Weir L, Speers C, Hayes MM, Baliski C, Tyldesley S. Population-based analysis of the impact and generalizability of the NSABP-B24 study on endocrine therapy for patients with ductal carcinoma in situ of the breast. Ann Oncol. 2015;26(9):1898-903. DOI: 10.1093/annonc/mdv251

36. Qian GW, Ni XJ, Wang Z, Jiang YZ, Yu KD, Shao ZM. Effect of radiotherapy on survival of women with locally excised ductal carcinoma in situ of the breast: a surveillance, epidemiology, and end results population-based analysis. Onco Targets Ther. 2015;8:1407-18. DOI: 10.2147/OTT.S82087

37. Koh VC, Lim JC, Thike AA, Cheok PY, Thu MM, Tan VK, et al. Characteristics and behaviour of screen-detected ductal carcinoma in situ of the breast: comparison with symptomatic patients. Breast Cancer Res Treat. 2015;152(2):293-304. DOI: 10.1007/s10549-015-3472-6

38. Mathew J, Karia R, Morgan DA, Lee AH, Ellis IO, Robertson JF, et al. Factors influencing local control in patients undergoing breast conservation surgery for ductal carcinoma in situ. Breast. 2017;(31):181-5. DOI: 10.1016/J.Breast.2016.11.002

39. Cronin PA, Olcese C, Patil S, Morrow M, Van Zee KJ. Impact of age on risk of recurrence of ductal carcinoma in situ: outcomes of 2996 women treated with breast-conserving surgery over 30 years. Ann Surg Oncol. 2016;23(9):2816-24. DOI: 10.1245/ S10434-016-5249-5

40. Elshof LE, Tryfonidis K, Slaets L, van Leeuwen-Stok AE, Skinner VP, Dif N, et al. Feasibility of a prospective, randomised, open-label, international multicentre, phase III, non-inferiority trial to assess the safety of active surveillance for low risk ductal carcinoma in situ - the Lord study. Eur J Cancer. 2015;51(12):1497-510. DOI: 10.1016/J.Ejca.2015.05.008 